\title{
Selectivity of pesticides used in peach orchards on the larval stage of the predator Chrysoperla externa (Hagen) (Neuroptera: Chrysopidae)
}

\author{
Seletividade de agrotóxicos utilizados no pessegueiro sobre o estágio \\ larval do predador Chrysoperla externa (Hagen) \\ (Neuroptera: Chrysopidae)
}

\author{
Rodolfo Vargas Castilhos ${ }^{1 *}$; Anderson Dionei Grützmacher²; Dori Edson Nava ${ }^{3}$; \\ Moisés João Zotti ${ }^{4}$; Paulo Ricardo Baier Siqueira5; Daniel Spagnol ${ }^{6}$
}

\begin{abstract}
The selectivity of sixteen pesticides used in peach orchards in Brazil was evaluated on larvae of Chrysoperla externa (Hagen) (Neuroptera: Chrysopidae) in laboratory $\left(25 \pm 1^{\circ} \mathrm{C}, 70 \pm 10 \% \mathrm{RH}\right.$ and 14 hours photophase). The bioassays consisted on the exposure of larvae to fresh dry pesticide film applied on glass plates. Lenght of each development stage, the mortality, the fecundity and fertility of survival adults were evaluated. Pesticides were classified according to the total toxic effect in harmless $(<30 \%)$, slightly harmful $(30-79 \%)$, moderately harmful $(80-99 \%)$ and harmful $(>99 \%)$, in conformity to "International Organization for Biological Control of Noxious Animals and Plants" (IOBC) recommendation. Only abamectin and deltamethrin caused significant prolongation in the post embryonic period. Fecundity and fertility of survival adults were not affected by any pesticide tested. The acaricide/insecticide abamectin, the two mineral oils, the fungicides mancozeb, dodine, azoxystrobin, captan, mancozeb + cooper oxichloride and pholpet, and the herbicide ghlyphosate were harmless; the fungicide tebuconazole was slightly harmful; the insecticide deltamethrin was moderately harmful; and the insecticides malathion, dimethoate and phosmet, and the herbicide paraquat dichloride were harmful to C. externa larvae.
\end{abstract}

Key words: Biological control, green lacewing, Prunus persica L., integrated pest management

\section{Resumo}

Foi avaliada neste trabalho a seletividade de dezesseis agrotóxicos utilizados na cultura do pessegueiro sobre o estágio larval de Chrysoperla externa (Hagen) (Neuroptera: Chrysopidae) em bioensaios conduzidos em laboratório (temperatura de $25 \pm 1^{\circ} \mathrm{C}$, umidade relativa $70 \pm 10 \%$ e fotofase 14 horas). Os bioensaios consistiram na exposição de larvas do predador a resíduos secos dos agrotóxicos pulverizados sobre placas de vidro. Foram avaliadas a duração dos estágios de desenvolvimento, a mortalidade, a fecundidade e fertilidade dos adultos remanescentes, sendo os agrotóxicos classificados

\footnotetext{
${ }^{1}$ Discente de Doutorado do curso de Pós-Graduação em Fitossanidade, Faculdade de Agronomia Eliseu Maciel, Universidade Federal de Pelotas, UFPel, Pelotas, RS, Brasil. E-mail: rvcastilhos@hotmail.com; rcastilhos.faem@ufpel.edu.br

2 Prof. do Curso de Pós-Graduação em Fitossanidade, UFPel, Pelotas, RS, Brasil. E-mail: anderson.grutzmacher@pq.cnpq.br

${ }^{3}$ Pesquisador da Embrapa Clima Temperado, Capão-do-Leão, RS, Brasil. E-mail: nava.dori@cpact.embrapa.br

${ }^{4}$ Dr. em Fitossanidade, UFPel, Pelotas, RS, Brasil.E-mail: zottimoises@yahoo.co.uk

${ }^{5}$ Discente do curso de Agronomia, UFPel, Pelotas, RS, Brasil. E-mail: agrosiqueira@yahoo.com.br

${ }^{6}$ Discente de Mestrado do curso de Pós-Graduação em Fitossanidade, UFPel, Pelotas, RS, Brasil. E-mail: spagnol.agro@hotmail. com

* Author for correspondence
} 
em função do efeito total como inócuos ( $<30 \%)$, levemente nocivos (30-79\%), moderadamente nocivos (80-99\%) e nocivos (>99\%), conforme recomendação da "International Organization for Biological and Integrated Control of Noxious Animals and Plants." Somente abamectina e deltametrina prolongaram significativamente o período pós-embrionário. A fecundidade e fertilidade dos adultos sobreviventes não foram afetadas por nenhum agrotóxico testado. $\mathrm{O}$ acaricida/inseticida abamectina, os dois inseticidas a base de óleo mineral, os fungicidas azoxystrobina, captana, dodina, folpete, mancozebe e mancozebe + oxicloreto de cobre e o herbicida glifosato são inócuos; o fungicida tebuconazole é levemente nocivo; o inseticida deltametrina é moderadamente nocivo e os inseticidas dimetoato, fosmete e malationa, e o herbicida dicloreto de paraquate são nocivos ao estágio larval de $C$. externa.

Palavras-chave: Controle biológico, crisopídeo, Prunus persica L., manejo integrado de pragas

\section{Introduction}

The State of Rio Grande do Sul is the largest peach producer in Brazil, with more than 14,900 hectares cultivated. Although large, its production has recorded a lower yield when compared to other Brazilian states (IBGE, 2012).

One of the main reasons for low-yielding is the occurrence of fruit insect pests such as the South American fruit fly Anastrepha fraterculus (Wiedemann) (Diptera: Tephritidae) the oriental fruit moth Grapholita molesta (Busck) (Lepidoptera: Tortricidae), aphids, and secondary pests such mites and peach scales (SALLES, 1998; BOTTON et al., 2011). Also, in the past decade, a pest that has been often occurring on peach orchards is the maize weevil Sitophilus zeamais Motschulsky (Coleoptera: Curculionidae), which can damage the fruits close to harvest (AFONSO et al., 2005).

Most farmers fight these insects making use of frequent application of organophosphorus insecticides, which have high toxicity and broad spectrum (BOTTON et al., 2011). The frequent use of the organophosphorus in this area of Brazil can also be explained by the climate of this region that favors the outbreak of insect pests for having high rainfall rates, high relative humidity and strong winds during spring and summer (FACHINELLO et al., 2003). This practice violates the rules recommended by the Integrated Pest Management (IPM), where management techniques, such as biological control, are expected in order to avoid excessive and unnecessary pesticides spraying.
Another reason to adopt a more conservative use of pesticides is the ever increasing demand of the consumers for high quality fruit, free of chemical residues and environmentally safe, making the adoption of IPM techniques necessary to minimize the use of pesticides in the orchards. Within this context, the use of beneficial insects for biological pest control has emerged as an alternative that should be encouraged (NAVA et al., 2006).

The beneficial fauna is directly affected by the practices adopted in the orchards. Atanassov, Shearer and Hamilton (2003) reported high number of natural enemies, and consequently a high rate of G. molesta eggs parasitism and predation in orchards where a reduced risk arthropod management program was implemented. Once the use of pesticides cannot be totally excluded in peach commercial production, farmers should choose the less toxic pesticides towards beneficial insects to achieve maximum compatibility between chemical and biological control, being the studies regarding of the side effect of pesticides on beneficial insects strongly recommended.

The Chrysopidae family naturally occurs in several agricultural habitats, including peach orchards (SCHUBER et al., 2008). These predators can act as control agents of a wide range of phytophagous insects such as caterpillars, aphids, mites and scale insects (CARVALHO; SOUZA, 2000). The green lacewing Chrysoperla externa (Hagen) (Neuroptera: Chrysopidae) is one of the most abundant and studied species in the Neotropical Region, including Brazil (FREITAS, 2002). Several 
studies about the side effects of pesticides were conducted with the specie Chrysoperla carnea (Stephens) (Neuroptera: Chrysopidae) using the methodology of the "International Organization for Biological and Integrated Control of Noxious Animals and Plants/West Palaearctic Regional Section" (IOBC/WPRS). This methodology consists on the evaluation of pesticides residual toxicity on lacewings larvae (the most susceptible stage) and also the sublethal effects that may occur on remain adults (VOGT et al., 2000; REZAEI et al., 2007; GIOLO et al., 2009). In Brazil, this kind of study was conducted with the neotropical specie $C$. externa for crops such as apple orchards, (MOURA et al., 2010), citrus (BUENO; FREITAS, 2004; GODOY et al., 2004), cotton (CARVALHO et al., 2002), coffee (VILELA et al., 2010) and cucumber (DACOSTA et al., 2008), however there has been no record of any study for peach orchards regarding the larval stage of this specie.

In this way, this work aimed to evaluate the lethal and sub-lethal effects of pesticides used in peach orchards on larvae of C. externa

\section{Material and Methods}

\section{Insects}

The insects were obtained from a colony maintained under laboratory conditions $\left(25 \pm 1^{\circ} \mathrm{C}\right.$, $70 \pm 10 \% \mathrm{RH}$ and 14 hours photophase), using an adaptation of the rearing methodology described by Carvalho and Souza (2000) and Vogt et al. (2000). The eighth and ninth generation larvae were used on the bioassays.

Larvae were kept until pupation in plastic trays (43 cm length x $27 \mathrm{~cm}$ width $\times 13 \mathrm{~cm}$ high) that were treated with talcum on lateral boards and closed with "Voile" fabric in order to avoid the larvae from escaping and to allow ventilation. Larvae were fed ad libitum with Anagasta kuehniella (Zeller) eggs. Layers of paper were added to the plastic trays to increase the foraging surface and to reduce intraspecific predation.

Approximately five days after pupation the insects were removed from the trays and transferred to acrylic cages $(15.5 \mathrm{~cm}$ high and $18.5 \mathrm{~cm}$ in diameter), which were closed with paper on both extremities for adults rearing. Distilled water was provided by capillarity through a role in the cage. An artificial diet composed by $15 \mathrm{~mL}$ of condensed milk, 1 egg, 1 egg yolk, $30 \mathrm{~g}$ of honey, $20 \mathrm{~g}$ of fructose, $30 \mathrm{~g}$ of dried brewer's yeast, $50 \mathrm{~g}$ of wheatgerm and $45 \mathrm{~mL}$ of distilled water (VOGT et al., 2000) was provided for adults feeding. Twice a week water and diet were replaced and the paper where the eggs were laid was collected and transferred to trays for hatching and beginning of a new cycle of the lacewing.

\section{Pesticides}

The sixteen pesticides tested on C. externa larvae were chosen among the ones most commonly used in peach orchards in Brazil. The concentrations used were the maximum field-recommended concentrations in accordance to the Brazilian registration (AGROFIT, 2010). Since IOBC recommends a standard deposit of $2 \mathrm{mg} / \mathrm{cm}^{2}$, which is equivalent to $200 \mathrm{~L} / \mathrm{ha}$, the concentrations of the pesticide solutions were adjusted to simulate a water deposit of $800 \mathrm{~L} / \mathrm{ha}$, trough the following equation: $C=M F R C \times F C \times F D$, in which: $C=$ concentration of pesticide solution used; $M F R C=$ maximum fieldrecommended concentration; $F C=4$ (correction factor for deposit rate); $F D=$ correction factor representing deposits under field conditions which in orchards, for foliage dwelling predators, is 0.4 (BARRETT et al., 1994; GRÜTZMACHER et al., 2004) (Table 1). 
Table 1. Pesticides used in peach orchards in Brazil and tested on Chrysoperla externa first-instar larvae.

\begin{tabular}{lllcccc}
\hline Pesticide & Active ingredient & Chemical group & $\mathbf{C}^{\mathbf{1}}$ & MFRC $^{\mathbf{2}}$ & \%.a.i. $^{\mathbf{3}}$ & \%c.p. $^{\mathbf{4}}$ \\
\hline Agritoato 400 & Dimethoate & Organophosphate & I & 250 & 0.160 & 0.400 \\
Assist & Mineral oil 1 & Hydrocarbons & I & 2000 & 2.420 & 3.200 \\
Decis 25 EC & Deltamethrin & Pyrethroid & I & 40 & 0.002 & 0.064 \\
Imidan 500 WP & Phosmet & Organophosphate & I & 200 & 0.160 & 0.320 \\
Malathion 500 EC & Malathion & Organophosphate & I & 300 & 0.240 & 0.480 \\
Oppa & Mineral oil 2 & Hydrocarbons & I & 1500 & 1.920 & 2.400 \\
Vertimec 18 EC & Abamectin & Avermectin & I/A & 80 & 0.002 & 0.128 \\
\hline Amistar 500 WG & Azoxystrobin & Strobilurin & F & 20 & 0.016 & 0.032 \\
Cuprozeb & Mancozeb + & Dithiocarbamate & F & 200 & $0.140+0.096$ & 0.320 \\
Dodex 450 SC & cooper oxichloride & Inorganic & F & 175 & 0.126 & 0.280 \\
Folicur 200 EC & Dodine & Guanidine & F & 100 & 0.320 & 1.600 \\
Folpan Agricur 500 WP & Tebuconazole & Triazol & F & 250 & 0.200 & 0.400 \\
Manzate 800 & Mancozeb & Dithiocarbamate & F & 200 & 0.256 & 0.320 \\
Orthocide 500 & Captan & Dicarboximide & F & 240 & 0.192 & 0.384 \\
\hline Gramoxone & Paraquat dichloride & Bipyridylium & H & $3 *$ & 0.300 & 1.500 \\
Roundup & Glyphosate & Glycine & H & $6 *$ & 1.440 & 3.000 \\
\hline Sumithion 500 EC & Fenitrothion & Organophosphate & I & 150 & 0.120 & 0.240 \\
\hline
\end{tabular}

${ }^{1}$ Class: $\mathrm{I}=$ insecticide, $\mathrm{F}=$ fungicide, $\mathrm{H}=$ herbicide, $\mathrm{A}=$ acaricide; ${ }^{2} \mathrm{MFRC}=$ Maximum field-recommended concentration $(\mathrm{g}$ or $\mathrm{ml} \mathrm{c.p.} / 100 \mathrm{~L}) * \mathrm{~L} / \mathrm{ha} ;{ }^{3 \%} \%$ a.i. $=$ Concentration $(\%)$ of active ingredient in the solution; ${ }^{40} \%$ c.p. $=$ Concentration $(\%)$ of commercial product in the solution.

Source: Elaboration of the authors.

\section{Bioassays}

The bioassays were performed in accordance to the guidelines established for the species $C$. carnea by the IOBC/WPRS Working Group "Pesticides and Beneficial Organisms" (VOGT et al., 2000). Due to the capacity of the experimental room (six treatments), the study was divided in four bioassays. Each bioassay was composed by four pesticides, a control (distilled water) and a positive standard (Sumithion 500 EC) of recognized toxicity (MOURA et al., 2010).

The pesticides were sprayed on glass plates with $50 \mathrm{~cm}$ length and $41 \mathrm{~cm}$ width with a $\mathrm{CO}_{2}$ pressurized spray calibrated on $50 \mathrm{psi}$, in order to realize a deposit of $2 \mathrm{mg} / \mathrm{cm}^{2}$. After the spray deposit dried the plates were transferred to a controlled environmental room $\left(25 \pm 1^{\circ} \mathrm{C}, 70 \pm 10 \% \mathrm{RH}\right.$ and 14 hours photophase) and covered with an acrylic plate with the same dimensions. The acrylic plate had twenty holes with a diameter of $7.5 \mathrm{~cm}$. Plastic rings were placed in each hole, forming individual exposure arenas.

One first-instar larvae (1-2 days old) was added per arena. Food was added ad libitum every two days and larvae were exposed to pesticides residue until pupation. Every treatment consisted of two plates with twenty arenas each, totalizing forty larvae.

The time for the development of each stage (first, second and third instars; pre-pupae and pupae) and the cumulative mortality observed in each treatment were recorded.

The treatments that registered less than 50\% mortality had the fecundity and fertility of the survivor adults assessed. The adults that emerged from the same treatment were collected and kept together in cages that had the same dimensions of those used for adults rearing. Approximately four days after emergency, adults were separated by 
sex and five couples per treatment were selected. One week after observation of the first egg laying, from four to six samples of eggs, corresponding to an oviposition period of 24 hours, were taken. Fecundity was measured as the mean number of eggs produced per female per day. The eggs attached to the paper of the superior extremity of each sample were incubated for hatching in trays in order to determine the fertility. The means of fecundity and fertility were compared to those obtained in the control of each bioassay.

\section{Data analysis}

Data regarding the length of each developmental stage, fecundity and fertility from all bioassays were analyzed according to their distribution through Shapiro Wilk normality test using the statistic software Assistat Version 7.6 (SILVA; AZEVEDO, 2009). For those variables that did not exhibit normal distribution, data were log transformed before submitted to analysis of variance. Means were compared by Tukey test $(\mathrm{p}<0.05)$ using the program Winstat Version 1.0 (MACHADO; CONCEIÇÃO, 2007).

The cumulative mortality in each treatment was calculated and corrected by the mortality observed in the control by the Schneider Orelli's formula (PÜNTENER, 1981). The effect of each pesticide was obtained based on the formula proposed by Vogt (1992): $E=100 \%-(100 \%-M \%) \times R 1 \times R 2$, in which $\mathrm{E}=$ total effect of the pesticide $(\%) ; \mathrm{M} \%=$ corrected mortality; $\mathrm{R} 1$ = ratio of mean number of eggs laid daily by treated females versus non treated females; R2 = ratio of mean fertility of eggs laid by treated females versus non treated females.
Pesticides were classified based on their total effect(E) and according to the IOBC laboratory scale in four toxicity categories: 1 , harmless $(<30 \%) ; 2$, slightly harmful (30-79\%); 3, moderately harmful (80-99\%); 4, harmful (>99\%) (HASSAN, 1994).

\section{Results}

The development stages of $C$. externa larvae significantly presented different periods of time when exposed to pesticide residues (Table 2). Malathion, phosmet, dimethoate and paraquat dichloride caused $100 \%$ mortality in first instar larvae, so it was not possible to assess the length of development stages from larvae exposed to these pesticides. The post-embryonic period (first instar up to adult) of survivors ranged from 19.3 to 27 days in the treatments of the four bioassays (Table 2).

Among the tested pesticides, only abamectin, in bioassay I, and deltamethrin, in bioassay II, caused significant prolongation in the post embryonic period of $C$. externa compared to the control. Abamectin affected the length of first instar larvae, which was of 4 days and differed significantly from the control. Pre-pupal and pupal stages of $C$. externa from first instar larvae exposed to abamectin lasted 4 and 7.3 days, respectively, and were both significantly longer than the control (Table 2).

Deltamethrin increased in four days the postembryonic development of the predator. This compound induced the longest lenght of first instar up to adult period (27 days) among all pesticides tested in the four bioassays (Table 2). 
Table 2. Development time of Chrysoperla externa first-instar larvae exposed to fresh residues of pesticides using the maximum field-recommended concentration in peach crop.

\begin{tabular}{|c|c|c|c|c|c|c|c|}
\hline \multirow{2}{*}{$\begin{array}{l}\text { Treatment } \\
1(n=40)\end{array}$} & \multirow{2}{*}{ MFRC } & \multicolumn{6}{|c|}{ Duration (days) } \\
\hline & & $1^{\text {st }}$ instar & $2^{\text {nd }}$ instar & $3^{\text {rd }}$ instar & Pre-pupal & Pupal & $\mathrm{L}_{1}$-adult \\
\hline \multicolumn{8}{|c|}{ Bioassay I } \\
\hline Control & - & $3.3 \pm 0.63 b$ & $2.7 \pm 0.45 \mathrm{a}$ & $2.9 \pm 0.23 \mathrm{a}$ & $3.4 \pm 0.55 b$ & $6.9 \pm 0.42 b$ & $19.3 \pm 0.47 b$ \\
\hline Abamectin & 80 & $4.0 \pm 0.69 \mathrm{a}$ & $2.9 \pm 0.35 \mathrm{a}$ & $2.3 \pm 0.44 b$ & $4.0 \pm 0.61 \mathrm{a}$ & $7.3 \pm 0.79 \mathrm{a}$ & $20.5 \pm 0.99 a$ \\
\hline Malathion & 300 & - & - & - & - & - & - \\
\hline Phosmet & 200 & - & - & - & - & - & - \\
\hline Dimethoate & 250 & - & - & - & - & - & - \\
\hline Fenithrotion (Standard) & 150 & - & - & - & - & - & - \\
\hline \multicolumn{8}{|c|}{ Bioassay II } \\
\hline Control & - & $3.1 \pm 0.39 \mathrm{a}$ & $4.1 \pm 0.32 b$ & $3.6 \pm 0.48 b$ & $3.1 \pm 0.27 b$ & $9.4 \pm 0.60 \mathrm{a}$ & $23.2 \pm 0.96 \mathrm{~b}$ \\
\hline Mineral oil 1 & 2000 & $3.3 \pm 0.62 \mathrm{a}$ & $4.3 \pm 0.54 b$ & $3.8 \pm 0.45 b$ & $3.2 \pm 0.36 \mathrm{~b}$ & $8.3 \pm 0.58 b$ & $22.9 \pm 0.88 b$ \\
\hline Mineral oil 2 & 1500 & $3.3 \pm 0.52 \mathrm{a}$ & $4.5 \pm 0.51 b$ & $3.7 \pm 0.68 \mathrm{~b}$ & $3.4 \pm 0.62 b$ & $8.3 \pm 0.61 b$ & $23.2 \pm 1.17 \mathrm{~b}$ \\
\hline Deltamethrin & 40 & $3.0 \pm 0.00 \mathrm{a}$ & $5.5 \pm 0.71 \mathrm{a}$ & $6.0 \pm 0.00 \mathrm{a}$ & $5.5 \pm 0.71 \mathrm{a}$ & $9.0 \pm 0.00 \mathrm{ab}$ & $27.0 \pm 1.41 \mathrm{a}$ \\
\hline Tebuconazole & 100 & $3.0 \pm 0.00 \mathrm{a}$ & $4.0 \pm 0.39 \mathrm{c}$ & $3.6 \pm 0.75 b$ & $3.4 \pm 0.58 b$ & $8.9 \pm 0.64 \mathrm{ab}$ & $22.8 \pm 1.31 b$ \\
\hline Fenithrotion (Standard) & 150 & - & - & - & - & - & - \\
\hline \multicolumn{8}{|c|}{ Bioassay III } \\
\hline Control & - & $3.8 \pm 0.66 \mathrm{a}$ & $4.3 \pm 0.49 \mathrm{a}$ & $3.3 \pm 0.65 b$ & $4.7 \pm 0.60 \mathrm{a}$ & $7.5 \pm 0.65 \mathrm{ab}$ & $23.6 \pm 0.76 \mathrm{a}$ \\
\hline Mancozeb & 200 & $3.5 \pm 0.60 \mathrm{a}$ & $4.3 \pm 0.44 \mathrm{a}$ & $3.3 \pm 0.56 b$ & $4.2 \pm 0.54 b$ & $7.0 \pm 0.51 \mathrm{c}$ & $22.2 \pm 1.00 \mathrm{~b}$ \\
\hline Dodine & 175 & $3.5 \pm 0.68 \mathrm{a}$ & $4.2 \pm 0.40 \mathrm{a}$ & $3.4 \pm 0.48 b$ & $4.8 \pm 0.63 \mathrm{a}$ & $7.2 \pm 0.52 \mathrm{bc}$ & $23.1 \pm 0.52 \mathrm{a}$ \\
\hline Azoxystrobin & 20 & $3.5 \pm 0.60 \mathrm{a}$ & $3.9 \pm 0.38 b$ & $3.7 \pm 0.62 \mathrm{a}$ & $4.8 \pm 0.62 \mathrm{a}$ & $7.7 \pm 0.48 \mathrm{a}$ & $23.5 \pm 0.86 \mathrm{a}$ \\
\hline Captan & 240 & $3.7 \pm 0.73 \mathrm{a}$ & $4.3 \pm 0.51 \mathrm{a}$ & $3.4 \pm 0.79 b$ & $4.8 \pm 0.76 \mathrm{a}$ & $6.9 \pm 0.51 \mathrm{c}$ & $23.2 \pm 1.12 \mathrm{a}$ \\
\hline Fenithrotion (Standard) & 150 & - & - & - & - & - & - \\
\hline \multicolumn{8}{|c|}{ Bioassay IV } \\
\hline Control & - & $2.7 \pm 0.46 \mathrm{a}$ & $2.8 \pm 0.42 \mathrm{a}$ & $2.8 \pm 0.53 b$ & $3.7 \pm 0.82 \mathrm{ab}$ & $8.2 \pm 0.75 \mathrm{a}$ & $20.2 \pm 0.49 \mathrm{a}$ \\
\hline $\begin{array}{l}\text { Mancozeb + copper } \\
\text { oxi. }\end{array}$ & 200 & $2.6 \pm 0.50 \mathrm{a}$ & $2.7 \pm 0.55 \mathrm{a}$ & $3.1 \pm 0.60 \mathrm{ab}$ & $3.8 \pm 0.41 \mathrm{a}$ & $8.2 \pm 0.54 \mathrm{a}$ & $20.4 \pm 0.69 \mathrm{a}$ \\
\hline Pholpet & 250 & $2.6 \pm 0.50 \mathrm{a}$ & $2.8 \pm 0.53 \mathrm{a}$ & $3.4 \pm 0.74 \mathrm{a}$ & $4.0 \pm 0.74 \mathrm{a}$ & $8.3 \pm 0.58 \mathrm{a}$ & $20.9 \pm 1.29 \mathrm{a}$ \\
\hline Glyphosate & $6^{*}$ & $2.8 \pm 0.54 \mathrm{a}$ & $2.9 \pm 0.36 \mathrm{a}$ & $3.2 \pm 0.47 \mathrm{a}$ & $3.5 \pm 0.50 \mathrm{~b}$ & $8.4 \pm 0.60 \mathrm{a}$ & $20.9 \pm 1.01 \mathrm{a}$ \\
\hline Paraquat dichloride & $3 *$ & - & - & - & - & - & - \\
\hline Fenithrotion (Standard) & 150 & - & - & - & - & - & - \\
\hline
\end{tabular}

MFRC $=$ Maximum field recommended concentration $(\mathrm{g}$ or $\mathrm{ml} / 100 \mathrm{l}) * 1 / \mathrm{ha}$.

Data (means \pm SE) followed by the same letter within the same column, were not significantly different $(p>0.05) .{ }^{1}$ initial number of larvae.

Source: Elaboration of the authors.

The two mineral oil formulations accelerated the pupal stage in comparison with the control in bioassay II (Table 2), however, for those products the first instar up to adult period did not differ significantly from the control.

Considering the seven fungicides tested, it was not observed negative interference of six of them in the lenght of the post-embryonic development, which varied from 20.4 to 23.5 days. Significant difference in first instar up to adult period occurred only for mancozeb, which caused reduction in the development of the predator. Also, the fungicide pholpet, and the herbicide glyphosate significantly prolonged the length of third-instar period; however, the first instarup to adult period was not significantly altered by these pesticides (Table 2).

Regarding the effect of the pesticides on the mortality and reproduction of $C$. externa when first-instar larvae were exposed to their residues (Table 3), the insecticides malathion, phosmet and 
dimethoate showed $100 \%$ mortality rates, similarly to fenithrotion (standard), and were framed in category 4 . For abamectin a mortality rate of $27.8 \%$ was recorded and no deleterious effect on the fecundity and fertility were observed, leading this pesticide to be classified as harmless (category 1). The two mineral oils tested were safe for C. externa, and fertility rates of survival adults were not significantly affected by any of them. Deltamethrin, caused mortality rate of $94.6 \%$ and was framed in category 3 (Table 3 ).

Except for tebuconazole, all fungicides were harmless with mortality rates ranging from zero to $2.7 \%$. Tebuconazole caused total effect of $31.2 \%$ and was classified as slightly harmful (category 2). Among the herbicides, glyphosate was safe, which showed total effect of only $4.3 \%$, while paraquat dichloride was harmful (category 4), providing $100 \%$ mortality rate for $C$. externa first-instar larvae (Table 3). Fecundity and fertility were not significantly affected by any fungicide or herbicide tested.

\section{Discussion}

The delay verified in our study (Table 2) in the length of first instar, pre-pupal and pupal stages of $C$. externa, of wich the first-instar larvae were exposed to abamectin, suggest that the energy spent for metabolic detoxification of this pesticide reflected on the predator development. According to Kliot and Ghanin (2012), fitness costs associated with pesticide resistance can occur in insects from different orders as a result of an energy reallocation for detoxification at the expense of developmental process, consequently affecting the development time. Similar result was obtained by Vilela et al. (2010), that studied the effect of acaricides on this predator and reported the duration of 4 days for the first instar in larvae treated with abamectin in a concentration of $0.225 \mathrm{~g} / \mathrm{L}$. However, the same author obtained a higher duration of the second and third instar in comparison with those obtained in our study, which may be explained by differences in exposure methods. In the cited study, the larvae were directly sprayed with the pesticide solution instead of being exposed to a treated surface, what probably leads to a higher penetration and assimilation of the active ingredient.

Only mancozeb caused anticipation in the development of $C$. externa (Table 2). However, a deleterious effect of this fungicide on $C$. externa larvae was not observed, since this fungicide acts as an inhibitor of enzymes involved with ATP production in fungi (STEPHENSON; SOLOMON, 2007), and caused no mortality on exposed larvae (Table 3). Results obtained with those fungicides in our study are in agreement with those obtained by Dacosta et al. (2008). The authors studied the effect of sulfur fungicides, mancozeb and copper oxychloride on C. externa larvae and found no negative interference in the duration of the larval and pupal stages, obtaining an average duration for post-embryonic development of 22.2 days, an amount that is within the range of values obtained with the fungicides tested in our study. Similarly, Silva et al. (2005) assessed the effect of pesticides used in coffee plants on C. externa larvae and found no negative interference in the duration of larval and pupal stage when larvae were sprayed with fungicides. The non-interference of fungicides in the duration of $C$. externa development it's helpful for its population establishment in peach orchards, once the prevention of diseases with fungicides may coincide with the occurrence of the first generations of the predator. 
Table 3. Cumulative mortality (\%), fecundity (eggs/female/day), fertility (\% of hatched larvae), total effect (E) (\%) and classification of the IOBC when Chrysoperla externa first-instar larvae were exposed to fresh residues of pesticides using the maximum field-recommended concentration for peach crop.

\begin{tabular}{|c|c|c|c|c|c|c|}
\hline Treatment & MFRC & $\mathbf{M}(\%)$ & Fecundity $^{1}$ & Fertility $^{1}$ & $\mathbf{E}(\%)$ & $\mathbf{C}$ \\
\hline \multicolumn{7}{|c|}{ Bioassay I } \\
\hline Control & - & - & $18.0 \pm 2.88 \mathrm{a}$ & $85.7 \pm 3.20 \mathrm{a}$ & - & - \\
\hline Abamectin & 80 & 27.8 & $20.9 \pm 4.89 \mathrm{a}$ & $83.6 \pm 5.25 \mathrm{a}$ & 18.0 & 1 \\
\hline Malathion & 300 & 100.0 & - & - & 100.0 & 4 \\
\hline Phosmet & 200 & 100.0 & - & - & 100.0 & 4 \\
\hline Dimethoate & 250 & 100.0 & - & - & 100.0 & 4 \\
\hline Fenithrotion (Standard) & 150 & 100.0 & - & - & 100.0 & 4 \\
\hline \multicolumn{7}{|c|}{ Bioassay II } \\
\hline Control & - & - & $19.3 \pm 2.58 \mathrm{a}$ & $83.5 \pm 1.11 \mathrm{a}$ & - & - \\
\hline Mineral Oil 1 & 2000 & 10.8 & $17.1 \pm 2.12 \mathrm{a}$ & $86.1 \pm 5.70 \mathrm{a}$ & 18.2 & 1 \\
\hline Mineral Oil 2 & 1500 & 24.3 & $18.8 \pm 3.86 \mathrm{a}$ & $91.0 \pm 3.17 \mathrm{a}$ & 19.3 & 1 \\
\hline Deltamethrin & 40 & 94.6 & - & - & 94.6 & 3 \\
\hline Tebuconazole & 100 & 35.1 & $19.7 \pm 1.88 \mathrm{a}$ & $86.9 \pm 2.86 \mathrm{a}$ & 31.2 & 2 \\
\hline Fenithrotion (Standard) & 150 & 100.0 & - & - & 100.0 & 4 \\
\hline \multicolumn{7}{|c|}{ Bioassay III } \\
\hline Control & - & - & $19.0 \pm 3.72 \mathrm{a}$ & $73.3 \pm 5.54 \mathrm{a}$ & - & - \\
\hline Mancozeb & 200 & 0.0 & $19.8 \pm 4.62 \mathrm{a}$ & $71.6 \pm 6.50 \mathrm{a}$ & 0.0 & 1 \\
\hline Dodine & 175 & 0.0 & $23.8 \pm 4.23 \mathrm{a}$ & $73.6 \pm 4.92 \mathrm{a}$ & 0.0 & 1 \\
\hline Azoxystrobin & 20 & 0.0 & $21.7 \pm 5.08 \mathrm{a}$ & $76.9 \pm 2.09 \mathrm{a}$ & 0.0 & 1 \\
\hline Captan & 240 & 2.6 & $20.3 \pm 3.28 \mathrm{a}$ & $73.3 \pm 5.31 \mathrm{a}$ & 0.0 & 1 \\
\hline Fenithrotion (Standard) & 150 & 100.0 & - & - & 100.0 & 4 \\
\hline \multicolumn{7}{|c|}{ Bioassay IV } \\
\hline Control & - & - & $16.5 \pm 4.95 \mathrm{a}$ & $78.2 \pm 9.87 \mathrm{a}$ & - & - \\
\hline Mancozeb + copper oxi. & 200 & 2.7 & $17.2 \pm 4.78 \mathrm{a}$ & $78.9 \pm 6.11 \mathrm{a}$ & 0.0 & 1 \\
\hline Pholpet & 250 & 2.7 & $15.8 \pm 5.89 \mathrm{a}$ & $69.0 \pm 4.52 \mathrm{a}$ & 17.8 & 1 \\
\hline Glyphosate & $6^{*}$ & 5.4 & $17.2 \pm 5.76 \mathrm{a}$ & $75.9 \pm 4.32 \mathrm{a}$ & 4.3 & 1 \\
\hline Paraquat dichloride & $3 *$ & 100.0 & - & - & 100.0 & 4 \\
\hline Fenithrotion (Standard) & 150 & 100.0 & - & - & 100.0 & 4 \\
\hline
\end{tabular}

MFRC $=$ Maximum field-recommended concentration $(\mathrm{g}$ or $\mathrm{mL} / 100 \mathrm{~L}) * \mathrm{~L} / \mathrm{ha} ; \mathrm{M}=$ Mortality corrected by Schneider-Orelli; $\mathrm{E}=\mathrm{Total}$ effect; $\mathrm{C}=$ Categories of the IOBC/WPRS (HASSAN, 1994), $1=$ harmless $(<30 \%), 2=$ slightly harmful $(30-79 \%), 3=$ moderately harmful (80-99\%), 4= harmful (>99\%).

${ }^{1}$ Mean obtained from 4 observations. Data (mean \pm SE) followed by the same letter within same column were not significantly different $(p>0.05)$.

Source: Elaboration of the authors.

For some pesticides, it was observed a significant delay or anticipation in specifics stages (Table 2), however, for most of them the first instar-adult period did not differ significantly from control except for abamectin, deltamethrin and mancozeb in bioassays 1, 2 and 3 respectively. This might be explained probably by a compensatory action between the different development stages, based on the statements of Metcalfe and Monaghan (2001), which pointed that organisms that experience an adverse period can subsequently show accelerated growth compensating for the initial stress. Differences between the duration of the development stages founded in this study and those found in the bibliography for a same active ingredient may occur due to differences in methods used on the experiments, differences in rearing conditions or even distinct provenances of $C$. externa populations (VOGT et al., 2000). 
The organophosphates malathion, phosmet and dimethoate were harmful to C. externa larvae (Table $3)$, therefore classified in category 4 (E>99\%). The high toxicity of organophosphorus for this specie has also been observed by Silva et al. (2005) and Ferreira et al. (2006) that obtained $100 \%$ of mortality for the organophosphate chlorpyrifos. Similarly to the results of our study, Silva et al. (2005) and Ferreira et al. (2006) found high toxicity of phosmet to larval stage of $C$. externa, getting a total effect around 80\%. Results from Moura et al. (2011) also confirmed the high toxicity of organophosphates. The referred authors related mortality rate of $100 \%$ on $C$. externa third instar larvae exposed to fenitrothion and methidathion.

Nonetheless, Giolo et al. (2009) studying the effects of different pesticides on larvae of C. carnea found no deleterious effect of organophosphate trichlorfon and phosmet, which were considered harmless $(\mathrm{E}<30 \%)$. These differences are probably due to the different concentrations of the active ingredients used, which were lower in the current study and to the better capacity for metabolic detoxification by $C$. carnea, which helped to diminish its mortality. Yet, for the insecticide dimethoate, Giolo et al. (2009) obtained high mortality (94.3\%) of larvae of C. carnea, which is close to the result obtained in our work to $C$. externa. Organophosphorus insecticides inhibit acetylcholinesterase, which is a class of enzyme that catalyzes the hydrolysis of the neurotransmitter acetylcholine (FUKOTO, 1990). This enzyme is common in the class Insecta, what explains the broad spectrum and high toxicity of this chemical group for insects.

The acaricide/insecticide abamectin showed 18\% total effect, being therefore classified as harmless (class 1) to the larvae of the predator C. externa (Table 3). Similar results were obtained by Bueno and Freitas (2004) for different concentrations of abamectin. Moura et al. (2010) has ranked abamectin as slightly harmful (category 2). However, the results of our study contrast with those observed by Vilela et al. (2010) that found $64.5 \%$ mortality to abamectin for a similar concentration of active ingredient, probably due to the fact that the larvae were directly sprayed.

The harmlessness of the two mineral oil formulations for predators was also related by Rocha et al. (2011) that obtained low toxicity of mineral oil for Cryptolaemus montrouzieri Mulsant (Coleoptera: Coccinellidae) larvae, confirming the low toxicity of this compound to predators. Thus, mineral oil can be used for controlling peach scales with no risk of impairing $C$. externa population in the orchards.

For deltamethrin, Godoy et al. (2004), assaying the same active ingredient, obtained $100 \%$ mortality for larvae of $C$. externa, while a mortality rate of $94.6 \%$ was observed in our study (Table 3). A similar result was also obtained by Silva et al. (2005) for the pyrethroid betacyfluthrin, confirming the harmful effects of insecticides belonging to this chemical group.

According to our findings, the fungicides tested, except tebuconazole, were harmless (category 1) (Table 3). These results were not surprising since most of fungicides have no known site of action in insects. However, Dacosta et al. (2008) grouped copper oxychloride, mancozeb and sulfur as slightly harmful (category 2) to C. externa larvae, differing from our study, which can be explained by the fact that the larvae have received direct application of the product rather than being exposed to the residual contact as in our work, thereby providing a greater exposure to the active ingredient or adjuvants. Given this, one realizes the importance of using standardized methodologies according to IOBC, since it facilitates the comparison of data obtained by different authors (DEGRANDE et al., 2002).

As for tebuconazole, the slightly harmfulness obtained differ from results found by Sterk et al. (1999) that classified the referred fungicide as harmless for the species $C$. carnea. So, differences in susceptibility between $C$. externa and $C$. carnea 
to the compound may be related to the different results reported.

Contrasting results were obtained for the two herbicides tested in our study (Table 3). While glyphosate proved to be harmless (category 1), paraquat dichloride was harmful (category 4), what leads the use of the last compound to be avoided when $C$. externa larvae are present in orchards and controlling insect-pests. According to Schneider et al. (2009), glyphosate did not show short term effects and mortality when third instar larvae of $C$. externa ingested eggs treated with this herbicide. However, deleterious effects were recorded on reproduction and longevity of adults, whereas in our study those sub-lethal effects were not observed. We highlight the differences in the exposure methods used in the cited study (ingestion) and our work (residual exposure), which can lead to different results regarding sub-lethal effects on reproduction. For the species C. carnea, Sterk et al. (1999) related no noxious effect of five different herbicides on residual exposure bioassays.

\section{Conclusions}

According to the results obtained in laboratory bioassays, the pesticides abamectin, azoxystrobin, captan, dodine, pholpet, glyphosate, mancozeb, mancozeb + copper oxychloride, mineral oil 1 and mineral oil 2 are harmless to $C$. externa larvae in laboratory, and their use for IPM should be encouraged in peach orchards. Tebuconazole is slightly harmful (category 2); deltamethrin is moderately harmful (category 3); dimethoate, malathion, paraquat dichloride, and phosmet are harmful (category 4) to C. externa larvae, and should therefore be avoided or used with restrictions in peach orchards.

Laboratorial tests of side effect of pesticides are important for provide accurate reports about the lethal and sub-lethal effects of pesticides on beneficial arthropods, and those that were selective to $C$. externa in laboratory should be recommended for use in IPM in peach orchards. For harmless pesticides (category 1) subsequent tests of selectivity are not required. Whereas for pesticides that showed toxicity (categories 2, 3 and 4), subsequent tests of semi-field (persistence) and field (peach orchards) are strongly recommended in order to prove their real impact on C. externa larvae.

\section{Acknowledgments}

To the Coordenação de Aperfeiçoamento de Pessoal de Nível Superior (CAPES) for the scholarship granted to the first author, to the Fundação de Amparo à Pesquisa do Estado do Rio Grande do Sul (FAPERGS) and Conselho Nacional de Desenvolvimento Científico e Tecnológico (CNPq) for the financial support to the project (064/2008).

\section{References}

AFONSO, A. P. S.; FARIA, J. L.; BOTTON, M.; LOECK, A. E. Controle de Sitophilus zeamais Mots., 1855 (Coleoptera: Curculionidae) com inseticidas empregados em frutíferas temperadas. Ciência Rural, Santa Maria, v. 35, n. 2, p. 253-258, 2005.

AGROFIT. Sistema de agrotóxicos fitossanitários. 2010. Disponivel em: <http://extranet.agricultura.gov. $\mathrm{br} /$ agrofit_cons/principal_agrofit_cons $>$. Acesso em: 12 jun. 2010.

ATANASSOV, A.; SHEARER, P. W.; HAMILTON, G. Peach pest management programs impact beneficial fauna abundance and Grapholita molesta (Lepidoptera: Tortricidae) egg parasitism and predation. Environmental Entomology, Lanham, v. 32, n. 4, p. 780-788, 2003.

BARRETT, K. L.; GRANDY, N.; HARRISON, E. G.; HASSAN, S. A.; OOMEN, P. Guidance document on regulatory testing procedures for pesticides with nontarget arthropods. Europe: Society of Environmental Toxicology and Chemistry, UK, 1994. 51 p.

BOTTON, M.; NAVA, D. E.; ARIOLI, C. J.; GRUTZMACHER, A. D.; GARCIA, M. S. Bioecologia, monitoramento e controle da mariposa-oriental na cultura do pessegueiro no Rio Grande do Sul. Bento Gonçalves: Embrapa Uva e Vinho, 2011. 11 p. (Embrapa Uva e Vinho: Circular técnica, 86). 
BUENO, A. F.; FREITAS, S. Effect of the insecticides abamectin and lufenuron on eggs and larvae of Chrysoperla externa under laboratory conditions. BioControl, Dordrecht, v. 49, n. 3, p. 277-283, 2004.

CARVALHO, C. F.; SOUZA, B. Métodos de criação e produção de crisopídeos. In: BUENO, V. H. P. (Ed.). Controle biológico de pragas: produção massal e controle de qualidade. Lavras, UFLA. 2000. p. 91-109.

CARVAlHO, G. A.; CARVALHO, C. F.; SOUZA, B.; ULHÔA, J. R. Seletividade de inseticidas a Chrysoperla externa (Hagen) (Neuroptera: Chrysopidae). Neotropical Entomology, Londrina, v. 31, n. 4, p. 615-621, 2002.

DACOSTA, R. R.; CARVAlHO, G. A.; CARVALHO, C. F.; COSTA, R. R. Ação de fungicidas utilizados na cultura do pepino sobre larvas de primeiro ínstar de Chrysoperla externa (Hagen, 1861) (Neuroptera: Chrysopidae) e os efeitos sobre suas fases subseqüentes. Arquivos do Instituto Biológico, São Paulo, v. 75, n. 3, p. 243-350, 2008.

DEGRANDE, P. E.; REIS, P. R.; CARVALHO, G. A.; BELARMINO, L. C. Metodologia para avaliar o impacto de pesticidas sobre inimigos naturais. In: PARRA, J. R. P.; BOTELHO, P. S. M.; CORRÊA-FERREIRA, B. S.; BENTO, J. M. S. (Ed.). Controle biológico no Brasil: parasitóides e predadores. São Paulo: Manole, 2002. cap. 5, p. 71-93.

FACHINELLO, J. C.; TIBOLA, C. S.; VICENZI, M.; PARISOTTO, M.; PICOLOTTO, L.; MATTOS, M. L. T. Produção integrada de pêssego: três anos de experiência na região de Pelotas-RS. Revista Brasileira de Fruticultura, Jaboticabal, v. 25, n. 2, p. 256-258, 2003.

FERREIRA, A. J.; CARVALHO, G. A.; BOTTON, M.; LASMAR, O. Seletividade de inseticidas usados na cultura da macieira a duas populações de Chrysoperla externa (Hagen, 1861) (Neuroptera: Chrysopidae). Ciência Rural, Santa Maria, v. 36, n. 2, p. 378-384, 2006.

FREITAS, S. O uso de crisopídeos no controle biológico de pragas. In: PARRA, J. R. P.; BOTELHO, P. S. M.; CORRÊA-FERREIRA, B. S.; BENTO, J. M. S. (Ed.). Controle biológico no Brasil: parasitóides e predadores. São Paulo: Manole, 2002. cap. 13, p. 209-219.

FUKOTO, T. R Mechanism of action of organophosphorus and carbamate insecticides. Environmental Health Perspectives, North Carolina, v. 87, n. 1, p. 245-254, 1990.

GIOLO, F. P.; MEDINA, P.; GRÜTZMACHER, A. D.; VIÑUELA, E. Effects of pesticides commonly used in peach orchards in Brazil on predatory lacewing Chrysoperla carnea under laboratory conditions. BioControl, Dordrecht, v. 54, n. 5, p. 625-635, 2009.
GODOY, M. S.; CARVALHO, G. A.; MORAES, J. C.; JÚNIOR, M. G.; MORAIS, A. A.; COSME, L. V. Seletividade de inseticidas utilizados na cultura dos citros para ovos e larvas de Chrysoperla externa (Hagen) (Neuroptera: Chrysopidae). Neotropical Entomology, Londrina, v. 33, n. 5, p. 639-646, 2004.

GRÜTZMACHER, A. D.; ZIMMERMANN, O.; YOUSEF, A.; HASSAN, S. A. The side-effects of pesticides used in integrated production of peaches in Brazil on the egg parasitoid Trichogramma cacoeciae Marchal (Hym., Trichogrammatidae). Journal of Applied Entomology, Berlim, v. 108, n. 6, p. 377-383, 2004.

HASSAN, S. A. Activities of the IOBC/WPRS working group pesticides and beneficial organisms. IOBC/WPRS Bulletin, Darmstat, v. 17, n. 10, p. 1-5, 1994.

INSTITUTO BRASILEIRO DE GEOGRAFIA E ESTATÍSTICA - IBGE. Banco de dados: lavoura permanente. 2012. Disponível em: <http://www.ibge. gov.br/estadosat/temas.php?sigla=rs\&tema=lavouraper manente2011>. Acesso em: 27 maio 2012.

KLIOT, A.; GHANIM, M. Fitness costs associated with insecticide resistance. Pest Management Science, West Sussex, v. 68, n. 11, p. 1431-1437, 2012.

MACHADO, A. A.; CONCEIÇÃO, A. R. WINSTAT sistema de análise estatística para windows-(versão 1.0). Pelotas: Núcleo de Informação Aplicada, Universidade Federal de Pelotas, 2007. Disponível em: <http://www. ufpel.edu.br/ machado $>$. Acesso em: 23 fev. 2010.

METCALFE, N. B.; MONAGHAN, P. Compensation for a bad start: grow now, pay later? Trends in Ecology \& Evolution. London, v. 16, n. 5, p. 254-260, 2001.

MOURA, A. P.; CARVAlhO, G. A.; COSME, L. V.; ALVES, E.; BOTTON, M.; SILVA, P. S. Toxicological and ultrastructural analysis of the impact of pesticides used in temperate fruit crops on Chrysoperla externa. Revista Brasileira de Entomologia, Curitiba, v. 55, n. 3, p. 411-418, 2011.

MOURA, A. P.; CARVALHO, G. A.; MOSCARDINI, V. F.; LASMAR, O.; REZENDE, D. T.; MARQUES, M. C. Selectivity of pesticides used in integrated apple production to the lacewing, Chrysoperla externa. Journal of Insect Science, Madison, v. 10, n. 121, p. 1-20, 2010.

NAVA, D. E.; SILVA, E. S.; GUIMARÃES, J. A.; DIEZRODRÍGUEZ, G. I.; GARCIA, M. S.; BATISTA FILHO, A.; LEITE, L. G.; RAGA, A.; SATO, M. E. Controle biológico de pragas das frutíferas. In: PINTO, A. S.; NAVA, D. E.; ROSSI, M. M.; MALERBO-SOUZA, D. T. (Org.). Controle biológico de pragas na prática. Piracicaba: CP 2, 2006. cap. 11, p. 113-129. 
PÜNTENER, W. Manual for field trials in plant protection. $2^{\text {nd }}$ ed. Basle: Ciba-Geigy Limited, 1981. 205 p.

REZAEI, M.; TALEBI, K.; NAVEH, V. H.; KAVOUSI, A. Impacts of the pesticides imidacloprid, propargite, and pymetrozine on Chrysoperla carnea (Stephens) (Neuroptera: Chrysopidae): IOBC and life table assays. BioControl, Darmstadt, v. 52, n. 3, p. 385-398, 2007.

ROCHA, L. C. D.; CARVALHO, G. A.; MOSCARDINI, V. F.; REZENDE, D. T. Seletividade de inseticidas utilizados em cultura cafeeira para larvas de Cryptolaemus montrouzieri Mulsant. Ciência Rural, Santa Maria, v. 41, n. 6, p. 939-946, 2011.

SALLES, L. A. B. Principais pragas e seu controle. In: MEDEIROS, C. A. B.; RASEIRA, M. C. (Ed.). A cultura do pessegueiro. Brasília, Embrapa - CPACT, 1998. p. 206-242.

SCHNEIDER, M. I.; SANCHEZ, N.; PINEDA, S.; CHI, H.; RONCO, A. Impact of glyphosate on the development, fertility and demography of Chrysoperla externa (Neuroptera: Chrysopidae): Ecological approach. Chemosphere, Amsterdam, v. 76, n. 10, p. 1451-1455, 2009.

SCHUBER, J. M.; MONTEIRO, L. B.; POLTRONIERI, A. S.; CARDOSO, N. A.; MIO, L. L. Influência de sistemas de produção sobre a ocorrência de inimigos naturais de afídeos em pomares de pessegueiros em Araucária-PR. Revista Brasileira de Fruticultura, Jaboticabal, v. 30, n. 2, p. 336-342, 2008.

SILVA, F. A. S. E.; AZEVEDO, C. A. V. Principal Components Analysis in the Software AssistatStatistical Attendance. In: WORLD CONGRESS ON COMPUTERS IN AGRICULTURE, 7., 2009. Reno-NVUSA. Proceeding... Reno-NV-USA: American Society of Agricultural and Biological Engineers, 2009. p. 22-24.

SILVA, R. A.; CARVALHO, G. A.; CARVALHO, C. F.; REIS, P. R.; PEREIRA, A. M.; COSME, L. V. Toxicidade de produtos fitossanitários utilizados na cultura do cafeeiro a larvas de Chrysoperla externa (Hagen) (Neuroptera: Chrysopidae) e efeitos sobre as fases subseqüentes do desenvolvimento do predador. Neotropical Entomology, Londrina, v. 34, n. 6, p. 951-959, 2005.
STEPHENSON. G. R.; SOLOMON, K. R. Pesticides and the environment. Guelph, Ontario: Canadian Network of Toxicology Centres Press, 2007. 427 p.

STERK, G.; HASSAN, S. A.; BAILLOD, M.; BAKKER, F.; BIGLER, F.; BLUMEL, S.; BOGENSHUTZ, H.; BOLLER, E.; BROMAND, B.; BRUN, J.; CALIS, J. N. M.; COREMANS-PELSENEER, J.; DUSO, C.; GARRIDO, A.; GROVE, A.; HEIMBACH, U.; HOKKANEN, H.; JACAS, J.; LEWIS, G.; MORETH, L.; POLGAR, L.; ROVERSTI, L.; SAMSOE-PETERSEN, L.; SAUPHANOR, B.; SCHAUB, L.; STAUBLI, A.; TUSET, J. J.; VAINIO, A.; VAN DE VEIRE, M.; VIGGIANI, G.; VINUELA, E.; VOGT, H. Results of the seventh joint pesticide testing programme carried out by the IOBC/WPRS - working group 'pesticides and beneficial organisms'. BioControl, Dordrecht, v. 44, n. 1, p. 99-117, 1999.

VILEla, M.; CARVAlHO, G. A.; CARVAlHO, C. F.; VILAS BOAS, M. A.; LEITE, M. I. S. Seletividade de acaricidas utilizados em cafeeiro para larvas de crisopídeos. Revista Ceres, Viçosa, v. 57, n. 5, p. 621$628,2010$.

VOGT, H. Untersuchungen zu nebenwirkungen von insektiziden und akariziden auf Chrysoperla carnea (Stephens) (Neuroptera: Chrysopidae). Mededelingen Rijksfaacuteit Landbouwwetenschappen te Gent, Gent, v. 57, n. 2b, p. 559-567, 1992.

VOGT, H.; BIGLER, F.; BROWN, K.; CANDOLFI, M. P.; KEMMETER, F.; KÜHNER, C.; MOLL, M.; TRAVIS, A.; UFER, A.; VIÑUELA, E.; WLADBURGER, M.; WALTERSDORFER, A. Laboratory method to test effects of plant protection products on larvae of Chrysoperla carnea (Neuroptera: Chrysopidae). In: CANDOLFI, M. P.; BLUMEL, S.; FORSTER, R.; BAKKER, F. M.; GRIMM, C.; HASSAN S. A.; HEIMBACH, U.; MEADBRIGGS, M. A.; REBER, B.; SCHMUCK, R.; VOGT, $\mathrm{H}$. (Ed.). Guidelines to evaluate side-effects of plant protection products to non-target arthropods. IOBC/ WPRS, Reinheim, 2000, p. 27-44. 